THE SPIRIT OF FREEDOM 
1. The Autobiography of an Unknown South African, by Naboth Mokgatle (1971)

2. Modernizing Racial Domination: South Africa's Political Dynamics, by Heribert Adam (1971)

3. The Rise of African Nationalism in South Africa: The African National Congress, 1912-1952, by Peter Walshe (1971)

4. Tales from Southern Africa, translated and retold by A. C. Jordan (1973)

5. Lesotho 1970: An African Coup under the Microscope, by B. M. Khaketla (1972)

6. Towards an African Literature: The Emergence of Literary Form in Xhosa, by A. C. Jordan (1973)

7. Law, Order, and Liberty in South Africa, by A. S. Mathews (1972)

8. Swaziland: The Dynamics of Political Modernization, by Christian P. Potholm (1972)

9. The South West Africa/Namibia Dispute: Documents and Scholarly Writings on the Controversy between South Africa and the United Nations, by John Dugard (1973)

10. Confrontation and Accommodation in Southern Africa: The Limits of Independence, by Kenneth W. Grundy (1973)

11. The Rise of Afrikanerdom: Power, Apartheid, and the Afrikaner Civil Religion, by T. Dunbar Moodie (1975)

12. Justice in South Africa, by Albie Sachs (1973)

13. Afrikaner Politics in South Africa, 1934-1948, by Newell M. Stultz (1974)

14. Crown and Charter: The Early Years of the British South Africa Company, by John S. Galbraith (1974)

15. Politics of Zambia, edited by William Tordoff (1974)

16. Corporate Power in an African State: The Political Impact of Multinational Mining Companies in Zambia, by Richard Sklar (1975)

17. Change in Contemporary South Africa, edited by Leonard Thompson and Jeffrey Butler (1975)

18. The Tradition of Resistance in Mozambique: The Zambesi Valley, 1850-1921, by Allen F. Isaacman (1976)

19. Black Power in South Africa: The Evolution of an Ideology, by Gail M. Gerhart (1978)

20. Black Heart: Gore-Brown and the Politics of Multiracial Zambia, by Robert I. Rotberg (1977)

21. The Black Homelands of South Africa: The Political and Economic Development of Bophuthatswana and KwaZulu, by Jeffrey Butler, Rotbert I. Rotberg, and John Adams (1977)

22. Afrikaner Political Thought: Analysis and Documents, Volume I: 1780-1850, by André du Toit and Hermann Giliomee (1983)

23. Angola under the Portuguese: The Myth and the Reality, by Gerald J. Bender (1978) 
24. Land and Racial Domination in Rhodesia, by Robin Palmer (1977)

25. The Roots of Rural Poverty in Central and Southern Africa, edited by Robin Palmer and Neil Parsons (1977)

26. The Soul of Mbira: Music and Traditions of the Shona People of Zimbabwe, by Paul F. Berliner (1978)

27. The Darker Reaches of Government: Access to Information about Public Administration in the United States, Britain, and South Africa, by Anthony S. Mathews (1979)

28. The Rise and Fall of the South African Peasantry, by Colin Bundy (1979)

29. South Africa: Time Running Out. The Report of the Study Commission on U.S. Policy Toward Southern Africa (1981; reprinted with a new preface, 1986)

30. The Revolt of the Hereros, by Jon M. Bridgman (1981)

31. The White Tribe of Africa: South Africa in Perspective, by David Harrison (1982)

32. The House of Phalo: A History of the Xhosa People in the Days of Their Independence, by J. B. Peires (1982)

33. Soldiers without Politics: Blacks in the South African Armed Forces, by Kenneth W. Grundy (1983)

34. Education, Race, and Social Change in South Africa, by John A. Marcum (1982)

35. The Land Belongs to Us: The Pedi Polity, the Boers and the British in the Nineteenth-Century Transvaal, by Peter Delius (1984)

36. Sol Plaatje, South African Nationalist, 1876-1932, by Brian Willan (1984)

37. Peasant Consciousness and Guerrilla War in Zimbabwe: A Comparative Study, by Terence Ranger (1985)

38. Guns and Rain: Guerrillas and Spirit Mediums in Zimbabwe, by David Lan 1985

39. South Africa without Apartheid: Dismantling Racial Domination, by Heribert Adam and Kogila Moodley (1986)

40. Hidden Struggles in Rural South Africa: Politics and Popular Movements in the Transkei and Eastern Cape, 1890-1930, by William Beinart and Colin Bundy (1986)

41. Legitimating the Illegitimate: State, Markets, and Resistance in South Africa, by Stanley B. Greenberg (1987)

42. Freedom, State Security, and the Rule of Law: Dilemmas of the Apartheid Society, by Anthony S. Mathews (1987)

43. The Creation of Tribalism in Southern Africa, edited by Leroy Vail (1989)

44. The Rand at War, 1899-1902: The Witwatersrand and Anglo-Boer War, by Diana Cammack (1990)

45. State Politics in Zimbabwe, by Jeffrey Herbst (1990)

46. A Democratic South Africa? Constitutional Engineering in a Divided Society, by Donald L. Horowitz (1991)

47. A Complicated War: The Harrowing of Mozambique, by William Finnegan (1992)

48. J. M. Coetzee: South Africa and the Politics of Writing, by David Attwell (1993) 
49. A Life's Mosaic: The Autobiography of Phyllis Ntantala, by Phyllis Ntantala (1992)

50. The Opening of the Apartheid Mind: Options for the New South Africa, by Heribert Adam and Kogila Moodley (1993)

51. Going for Gold: Men's Lives on the Mines, by T. Dunbar Moodie with Vivienne Ndatshe (1994)

52. The Spirit of Freedom: South African Leaders on Religion and Politics, by Charles Villa-Vicencio, with a foreword by Thomas G. Karis (1996) 


\title{
THE SPIRIT OF FREEDOM
}

\author{
South African Leaders on \\ Religion and Politics
}

\section{CHARLES VILLA-VICENCIO}

With a Foreword by Thomas G. Karis

Interviews with Neville Alexander, Ray Alexander, Franz Auerbach, Cheryl Carolus,

Frank Chikane, Sheena Duncan,

Ela Gandhi, Nadine Gordimer, Chris Hani,

Trevor Huddleston, Nelson Mandela,

Govan Mbeki, Fatima Meer, Stanley Mogoba,

Ruth Mompati, Itumeleng Mosala,

Beyers Naudé, Ebrahim Rasool,

Albertina Sisulu, Joe Slovo, Desmond Tutu

UNIVERSITY OF CALIFORNIA PRESS

Berkeley Los Angeles London 
University of California Press

Berkeley and Los Angeles, California

University of California Press, Ltd.

London, England

(C) 1996 by

The Regents of the University of California

Originally published by Skotaville Publishers, Johannesburg, South Africa

\section{Library of Congress Cataloging-in-Publication Data}

Villa-Vicencio, Charles.

The spirit of freedom : South African leaders on religion and politics / Charles Villa-Vicencio ; with a foreword by Thomas Karis.

p. cm. - (Perspectives on South Africa ; 52)

Includes bibliographical references.

ISBN 0-520-20044-6 (alk. paper). - ISBN 0-520-20045-4 (pbk. : alk. paper)

1. Religion and politics-South Africa. 2. South Africa-

Religion-20th century. 3. South Africa-Politics and

government-1989- 4. South Africa-Politics and government-20th

century. 5. Political activists-South Africa-Interviews.

I. Title. II. Series.

BL2470.S6V55 1996

291.1'77'0968-dc20

Printed in the United States of America

$\begin{array}{lllllllll}9 & 8 & 7 & 6 & 5 & 4 & 3 & 2 & 1\end{array}$

The paper used in this publication meets the minimum requirements of American National Standard for Information Sciences-Permanence of Paper for Printed Library Materials, ANSI Z39.48-1984. (0) 